\title{
Some approaches to classification of dictionaries in lexicography
}

\author{
O. V. Gordiyenko
}

\author{
Zaporizhzhia State Medical University, Zaporizhzhia, Ukraine \\ Corresponding author. E-mail: olena.gord@gmail.com, orcid.org/0000-0003-2936-2630
}

Paper received 29.12.19; Accepted for publication 18.01.20.

\begin{abstract}
https://doi.org/10.31174/SEND-Ph2020-216VIII64-06
\end{abstract}
\begin{abstract}
This research was done in the field of theoretical lexicography and reflects the results of one stage of English medical terminography complex study. The work highlights some main approaches to typological classification of general and specialized dictionaries. The paper analyzes traditional typological classifications in general lexicography using a classification approach. It suggests the basic principles of classification in LSP (languages for specific purposes) lexicography of the subject area medicine. The study reveals that the basic principle of the typological classification of English medical reference works is the way of specific term(s) description: the relationship of the term with the concept and the object of description, as well as, the linguistic characteristics of the term as the element of the language for specific purposes.
\end{abstract}

Keywords: lexicography, typological classification, medical terminography, medical term, factual reference works, terminographic dictionary.

Introduction. Different works in the field of lexicography were and has remained relevant, taking into account the scientific and technological progress of all areas of knowledge and the need for constant productive communication at the global level. Particularly urgent in lexicography is the issue of typological classification of dictionaries (reference works), the solution of it contributes to the development of clear methods and approaches to creating dictionaries of various types taking into account the user. This article reflects the results of one of the stages of a comprehensive study on the study of English medical lexicography (terminography). Medical lexicography - a complex of activities concerned with the design, compilation, use and evaluation of reference works in the field of medicine» [11, p. 93].

The work highlights main approaches to typological classification of general and specialized dictionaries. The paper based on classification approach analyzes a comprehensive characterization of traditional typological classifications in general lexicography. It suggests the basic principles of classification in LSP (languages for specific purposes) lexicography of the subject area medicine. The study reveals the basic principle of the typological classification of English medical reference works with the focus on the way of specific term(s) description: the relationship of the term with the concept and the object of description, as well as, the linguistic characteristics of the term as the element of the language for specific purposes.

The aim of the paper to analyze traditional typological classifications in general lexicography with the subsequent development of the basic principles of dictionaries classification in English medical terminography.

Materials and methods. The study has complex methodology and consists of analytical review of literature (to study the theoretical literature in study field), classification approach (to analyse existing trends and approaches in typological classification), typological approach (to develop medical dictionary classification), method of juxtaposition (to reveal the final results).

A brief review of publications on the subject. The typological description of dictionaries is one of the main research methods in theoretical lexicography, because, firstly, it allows you to organize the whole variety of dictionary products and, secondly, it helps to compile dictionaries, the structure and content of which are aimed at a specific consumer [25, p. 222-223]. In the context of the tasks of this work, a typological description, in addition, allows to identify the main trends in the development of English medical lexicography.

In all the works we have studied in the field of theoretical lexicography, an indispensable component is the typological component. As R. Hartman notes, no one knows how many dictionaries have been created over the entire history of lexicography in various cultures, regions and countries $[9, \mathrm{p}$. 68]. Despite the existing experience in creating lists of dictionaries and bibliographies [2, 3, 7, 12, 14], scientific ordering of dictionary products is still very far from completion, especially focusing on the active work on the development of new types of dictionaries $[10,22]$ and taking into account the dictionaries of the electronic format.

Typological investigations are significant both theoretically and practically. From a theoretical point of view, their significance is due to the need to develop and unify the parameters of dictionaries of various types. From a practical point of view - to correlate all aspects of the dictionary with what the user expects to find in a dictionary of a particular type.

The reference literature, which is a collection of works of various genres and types, is a very difficult task for those metalexicographers and dictionary researchers who direct their efforts to its taxonomic ordering. However, despite the large amount of literature devoted to the typological study of lexicography, the terminological apparatus is in the process of development, therefore, the terms used by us in the description of methods and approaches are of a working nature.

Results and discussion. 1. The analysis of traditional approaches to the typological classification of dictionaries. The main method («classical» according to R.R.K. Hartmann) [9, p. 70], which is viewed in various modifications of classifications of dictionaries considered by us, is the method of contrast proposed L.V. Shcherba [20]. When creating a typology L.V. Shcherba, based on data from the dictionaries of Russian, Czech, French, English, German, Dutch, Swedish, Danish and many other languages, put forward six oppositions: 1. purpose: an academic type dictionary - a reference (specialized) dictionary; 2. content: encyclopaedic dictionary - general dictionary; 3. volume: thesaurus - ordinary (explanatory or translated) dictionary; 4. order: alphabetical - ideological (thematic); 5. number of languages: explanatory dictionary - translational; 6 . historical perspective: synchronic - historical vocabulary [20].

In these contrasts, the main types of dictionaries are named. They are fundamental and in the analysis in one form 
or another can be traced in subsequent classifications. The importance of this typology also lies in the fact that it is not presented in the form of a detailed classification - a scheme that includes all the variety of dictionary editions. The classifications with given non-overlapping characters are not promising, because there are few dictionaries with noncrossing features (and it is becoming smaller), and therefore, it is always possible to attribute the same dictionary for different characteristics simultaneously to different classes.

An exceptionally significant role was given by L.V. Shcherba to explanatory dictionary of the academic type. The history of Russian lexicography can be represented as the history of the creation of an ideal academic dictionary, therefore, the question of the normative orientation of Russian explanatory lexicography was constantly in the spotlight. L.V. Shcherba suggested for the selection of facts and phenomena as the part of the system of literary language, not of a narrowly normative (low standard), but of academic point of view (as the French Academy did, for example).

In subsequent years, researchers use a different set of contrasting criteria, but the approach itself remains basically unchanged. Studying the typological approach in the theory of lexicography, we examined the basic classifications developed in linguistics: typologies of A. Al-Kazimi, V.V. Dubichinskiy, V. G. Gak, R. Gouws, S.V. Grinev, R.R.K. Hartmann, R.Yu. Kobrin, S. Landau, J. Malkil, V.V. Morkovkin, A. Ray, V.F. Romenskaya, L. Zgusta. The authors of these classifications use different terminology and varying degrees of specifications (details).

Thus, a typological classification based on practical observations was proposed by V.V. Dubichinskiy distinguishes the following types of dictionaries:

- $\quad$ according to the number of languages described: monolingual, bilingual, multilingual

- $\quad$ according to vocabulary: dictionaries describing vocabulary "without limits"; dictionaries describing only certain lexical strata

- $\quad$ according to volume: unabridged (big), pocket (small), lexical minimums

- $\quad$ according to design of information: computer, paper

- according to functional orientation: specialized (terminological), special (linguistic)

- $\quad$ according to the order of lexical material presentation: semasiological, alphabetic (explanatory, spelling, etc.); onomasiological (thesauri, ideographic, etc.); alphabetic/reverse (derivational, etc.)

- from a cultural point of view: onomastic (toponyms, dictionaries of names and surnames, etc.); area studies (dictionaries of equivalence vocabulary, etc.); dictionaries on the culture of speech and the literary norm (spelling, orthoepic, etc.)

- mixed or complex dictionaries: explanatorycompatible, explanatory-translating, etc.

- training (learner's) dictionaries: regional, phraseological, etc. [6, p. 21-23].

The terminological uncertainty in the field of dictionaries typology suggested to develop the classification of typologies, which was done by V.G. Gak, who classifies typologies, highlighting five main distinguishing features:

- $\quad$ according to the object of classification: globalistic, atomistic and mixed.

- $\quad$ according to the totality of the facts under consideration: complete and selective.
- according to the criteria underlying: pluralistic and monistic.

- $\quad$ according to the purpose: static and dynamic.

- according to the order of the material presentation: by opposition, tree-like and radial.

Concluding the discussion of this issue, we emphasize that the typological characteristic of dictionaries is not the final purpose itself, but is aimed at improving of lexicography art and craft. In our case, the development of the principles of typological classification of English medical dictionaries, followed by the development of lexicographic methods of dictionaries creation.

2. The main approaches to the typological classification of English medical dictionaries. To compile a typological classification of English medical dictionaries, it is necessary to distinguish the definitions of such notions as "word", "concept", "term", to determine their functions and place in terminography. So, first, we analyzed the approaches of a number of general linguistic (suggested by O.S. Akhmanova, L.P. Stupin, V.N. Yartseva et al.), lexicographical (suggested by K.Ya. Averbukh, R.R.K. Hartmann, O.M. Karpova et al.), terminological (suggested by A.V. Lemov, V.M. Leichik, D.S. Lotte, A.V. Superanskaya et al.) schools; second, compared them with our observations. As a result, we came to the following conclusions.

"Word" is the basic structural unit of a language for expressing a concept whose main functions are nomination, communication. In its turn, "term" (from the Latin terminus $\sim$ border, limit) is a word or phrase denoting the concept of a special field of knowledge or activity.

Under the "concept" in our work, we understand the logically formed general idea of the subject. The term is associated with a specific scientific concept and has a conceptual, systematic and unambiguous nature. The main functions of the term are informativeness, nominativity, storage, transmission and exchange of scientific information.

There are disagreements among lexicographers about the unit of description of terminology in the literary/national language (LGP - language for general purposes): the lexical unit is "word" or "term". This issue is not discussable for terminographers, as they deal with the codification and registration of a special language (LSP), limited to a certain conceptual sphere in a special field without stylistic colouring [17, p. 508-509].

Conceptually, in terminography the unit of description is a "term", represented as a symbol by a word or phrase, within its system, has its definition, monosemantics within its terminology and having stylistic neutrality. Following R.R.K. Hartmannn, in terminography "term" is clearly tied to the special conceptual context of a certain field of knowledge and the fixation of the concept goes from concept to term, and not from word to meaning, as in general lexicography [11, p. 138-139].

This approach is reflected in the use of a mixed linguisticencyclopaedic definition when registering a "term", which is clearly seen in practical terminography in various types of English medical dictionaries.

When developing a typology of English-language medical reference works, one cannot omit such a linguistic term as "nomen", the understanding of which allows us to divide English medical reference works into factual and terminographic (linguistic). Following the philosophy of G.G. Shpeta, "nomen" is a unit of lexis, with the help of which a visible subject is named without establishing its exact place 
in the classification system and without correlation with others [21]. In medical nomenclatures, "nomen" is used without context, is not associated with the concept, it is the so-called nomenclature sign. So medical nomenclatures, compendiums, catalogs, codes, etc. are the so-called lists of medical terms, do not have a definition and linguistic characteristics, therefore they were named as factual.

Taking into account all of the above, while developing the typological classification of English medical dictionaries, we used formal characteristics of dictionaries (size, structure, format, functionality, number of languages, targeted user) and linguistic (term, spelling, phonetics, morphology, etymology, conceptual context, semantics).

The studied linguistic approaches and our own observations obtained after analysis of the formal and linguistic characteristics of dictionaries created in the framework of English medical terminography allowed us to develop the following approaches and principles to the typology of medical dictionaries.

So, it is suggested to divide initially the entire set of English medical reference works into two types: factual and terminographic (linguistic). The basis of this classification is the principle of correlation of a term with a concept and an object of description (see this discussion above), as well as, a method for describing the linguistic and non-linguistic characteristics of terms recorded in various dictionary types.

Studying the parameters of factual English medical dictionaries, allowed us to attribute to them the following types of medical reference works: nomenclature, catalog, index dictionary, compendium, atlas, reference book, on-line coding systems (e.g. SNOMED CT; Sobotta Anatomy Atlas; Terminologia Anatomica, 2011; Terminologia Histologica, 2008; UMLS (Unified Medical Language System)).

To terminographic reference works we classified medical encyclopaedias and dictionaries registering the linguistic characteristics of a medical term (e.g. Desk encyclopedia of human and medical virology, 2010; Dorland's Illustrated Medical Dictionary, 2012; Merriam-Webster Medical Dictionary, 2016;) sometimes with inclusion of non-linguistic characteristics.

In its turn, the study of the parameters of terminographic (linguistic) English medical dictionaries made it possible to divide them into two subgroups: according to the formal characteristics and linguistic parameters.

The formal criteria included such criteria as targeted user, design and volume of reference works. To linguistic parameters - the number of languages, the area and unit of description, the function of the dictionary, the order of dictionary entries, the type and structure of the dictionary entry.

Conclusions. Our investigation has revealed that there are different trends and approaches to typological classification of reference works in theory of lexicography based on the method of contrast. The analysis of theoretical literature in the field of terminology and terminography, complex study of reference works created in the frame of English medical terminography have shown that factual and terminographic characteristics should be in the base of typological classification of medical dictionaries. The study has demonstrated that the basic principle of the typological classification of English medical reference works is the way of specific term(s) description: the relationship of the term with the concept and the object of description, as well as, the linguistic characteristics of the term as the element of the language for special purposes. The obtained results will help to develop more detailed classification of medical dictionaries with further work out of a specialized dictionary structure taking into consideration a concept of description and a dictionary user.

\section{REFERENCES}

1. Averboukh K. Ya. Obshchaya teoriya termina [General theory of the term]. Ivanovo: Izd-vo Ivan. gos. un-ta, 2004.252p. (in Rus.).

2. Cop M. Babel unraveled. An annotated world bibliography of dictionary bibliographies. Tübingen: M. Niemeyrer, 1990. 195 p.

3. Delby A. Guide to world language dictionaries. London: Library Association, 1998. $470 \mathrm{p}$.

4. Desk encyclopedia of human and medical virology. Oxford: Academic, 2010. 642 p.

5. Dorland`s Illustrated Medical Dictionary. Elsevier: Saunders, 32nd edition, 2012. $2147 \mathrm{p}$.

6. Dubichinskiy V.V. Iskusstvo sozdaniya slovarey: Konspekty po leksikografii [The art of dictionary making]. Kharkov: KhGPU, 1994. - P. 18-23. (in Rus.).

7. Dubichinskiy V.V. Ukrainskaya leksikografiya: istoriya i sovremennost [Ukrainian lexicography] // Slovyanskaya leksikografiya: mezhdunar. rollektivnaya monografiya/ed. by M.I. Chernyshsheva. - Moskva: ITs Azbukovnik, 2013. - P. 251-309

8. Gak V.G. Para unatipología de las tipologías de diccionarios // Voz y Letra. Revista de Filología, 1991. Vol.II. № 1. P. 105-115.

9. Hartman R.R.K. Teaching and researching lexicography. Harlow, England: Pearson Educational Ltd., 2001. 211 p.

10. Hartmann R.R.K. Pure or hybride? The development of mixed dictionary genres // Facta Universitatis Series: Linguistics and Literature, 2005.Vol.3, No 2. P. $193-208$.

11. Hartmann R.R.K., James G. Dictionary of Lexicography. London \& New York: Routledge, 2002.

12. Kabdebo Th. Dictionary of dictionaries. London: Bowker-Saur, 1992. $253 \mathrm{p}$.

13. Karpova O. M., Shcherbakova Ye. V. PR: problemy terminograficheskogo opisaniya [PR: issues of terminographic discription]. Ivanovo: Ivan. gos. un-t, 2005. 183 c. (in Rus.).

14. Kister K.F. Dictionary buying guide. A consumer guide to gen-

eral English language wordbooks in print. New York: R.R. Bowker Co, 1977. 358 p.

15. Landau S. I. Dictionaries: The Art and Craft of Lexicography. 2nd edn. Cambridge: Cambridge University Press, 2001. 496 p.

16. Lemov A. V. Sistema, struktura i funktsionirovanie nauchnogo termina [System, structure and functioning of the scientific term]. Saransk: Mordovia Univ. Publ., 2000. 359 c. (in Rus.).

17. Linguistic: A Large Encyclopedic Dictionary. Series: Great Encyclopedic Dictionary/ed. by Yartseva V.N. 2000.688 c. (in Rus.).

18. Lotte D. S. Osnovy postroeniya nauchno-tekhnicheskoy terminologii [The basics of scientific and technical terminology composition]. - M.: AN SSSR,1961. 157 p. (in Rus.).

19. Merriam-Webster Medical Dictionary. Springfield, Massachusetts: Meriam Webster, Incorporated. 2016. 865 p.

20. Shcherba L. V. Opyt obshchey teorii leksikografii: Etyud I. Osnovnye tipy slovarey [The experience of general theory of lexicography] // Izvestiya Akademii Nauk Soyuza SSR. - M.: Izdvo AN SSSR, 1940. T. I. № 3. P. 89-117. (in Rus.).

21. Shpet G.G. Mysl i Slovo. Izbrannye trudy [Thought and word]/ed. by T. G. Shchedrina. M.: ROSSPEN, 2005. 688 p. (in Rus.).

22. Skybina V. Australian Lexicography: A History and Typology // New Trends in Lexicography: Ways of Registering and Describing Lexis/ed. by O. Karpova, F. Kartashkova. Cambridge: Cambridge Scholars Publishuing, 2010. Ch. 11. P. 100-119.

23. Terminologia Anatomica: International Anatomical Terminology. Stuttgart ; New York: Thieme, 2011. 292 p.

24. Terminologia Embryologica: intenational embryological terminology. Federal International Programme on Anatomical Terminologies. Stuttgart: Thieme, 2013. 288 p.

25. Zgusta L. Manual of Lexicography. The Hague: Prague Academia, $1971.360 \mathrm{p}$. 